\title{
Mass Movements Susceptibility analysis and Assessment of Associeted Risks along the Southern Escarpment of the Bamileke Plateaus (West-Cameroon Highlands)
}

\section{Raoul Merlin NDONBOU}

Department of Earth Sciences, Faculty of Science, University of Dschang

David Guimolaire Nkouathio ( $\square$ nkouathio@yahoo.fr)

Department of Earth Sciences, Faculty of Science, University of Dschang https://orcid.org/0000-00016231-7546

\section{Ghislain ZANGMO TEFOGOUM}

Department of Earth Sciences, Faculty of Science, university of Maroua

\section{Christian Suh GUEDJEO}

Department of Geology, Higher Teacher Training College, University of Bamenda

\section{Sylvie Noelle DJUKEM FENGUIA}

Department of Earth Sciences, Faculty of Science

\section{Paul TEMATIO}

\section{Department of Earth Sciences, Faculty of Science}

\section{Research Article}

Keywords: Escarpment, Bamileke Plateaux, mass movements, landslide susceptibility, West-Cameroon Highlands

Posted Date: May 16th, 2021

DOI: https://doi.org/10.21203/rs.3.rs-502477/v1

License: (c) (i) This work is licensed under a Creative Commons Attribution 4.0 International License. Read Full License 


\section{Abstract}

The Southern Escarpment of the Bamileke Plateaux (SEBP) is an area frequently affected by mass movements. An analysis of the susceptibility of these hazards is important in order to better understand these mountain processes. Field campaigns as well as the exploitation of satellite images in the laboratory have made it possible to inventory all sites subject to mass movements in the region. The region is affected by landslides, block falls and subsidence. Landslides are the most frequent hazard in the region. These hazards are regulated by about 10 natural and anthropogenic factors which include lithology, geomorphology, anthropogenic action, soil, proximity to roads, proximity to watercourses, density of watercourses, slope, direction of slopes, and curvature of slopes. The steepest slopes are between 27 and $90^{\circ}$, the most important slopes are oriented Nord-West. The curvature of the slopes shows zero, convex and concave slopes. The soils in the area are ferralitic, humus-bearing and

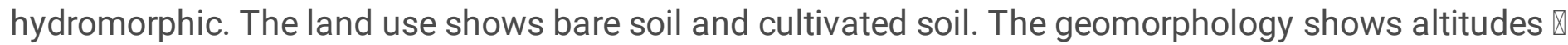
$1319 \mathrm{~m}$, the highest stream densities range from 183-293m and constitute the significant proximities causing instabilities. In relation to the different classes of river proximity, the highest river proximities are $\bigotimes 120 \mathrm{~m}$. The highest road proximities are $\nabla 50 \mathrm{~m}$ relative to the other road proximity classes. The geological formations that dominate the area are basalts, mylonites, granites gneisses and charnokites. These factors were mapped and the different maps were overlaid to obtain a mass movement susceptibility map of the study area. This map shows that $16.95 \%$ represent low probability areas, $43.39 \%$ represent moderate probability areas, $29.77 \%$ represent high probability areas and $9.89 \%$ represent very high probability areas. The majority of mass movements, especially landslides, are located in the high probability areas.

\section{Introduction}

Mass movements are natural hazards that generally affect steep and unstable slopes with adequate lithological, soil and geomorphological characteristics to contribute to the hazard. Mass movements are generally constituted by subsidence, landslides, mudslides, rock falls, landslides and collapses... These mass movements are influenced by a number of conditioning factors. These are the predisposing factors which add to the triggering factors such as rainfall and earthquakes.

The world has been threatened by mass movements and this has resulted in a number of casualties and property losses. Risk vulnerability assessment studies clearly confirm the importance of the consequences of mass movements. For example, in French republic, the department of Aude received during the night of Sunday 14 to Monday 15 October 2018, the equivalent of three months of rainfall in a few hours, causing deadly mudslides. According to the French newspaper Le Parisien, the toll is estimated at eleven (11) dead, eight (08) seriously injured and two (02) missing, with more than 1000 people evacuated. In the same country, in the Barcelonnette basin (Alpes-de-Haute-Provence), several landslides caused the temporary closure of communication routes, leading to major disruption of road traffic (Flageollet et al., 1999). The town of Stoze in Slovenia experienced a damaging landslide on 15 
November 2000. Seven people were killed in their homes, 23 residential buildings were damaged and 15 hectares of agricultural land were devastated (Brilly et al., 2002).

In Cameroon, the risks associated with mass movements are as important as in the rest of the world. Landslides are the most recurrent type of mass movement, accounting for $25 \%$ of natural hazards (Tchindjang, 2012) and are more localised in the equatorial part of the country. These mass movements are found along the Cameroon Volcanic Line with a peak of occurrence on the West Cameroon Highlands (WCH) (Aboubakar et al., 2013). They are the cause of loss of life and property. Examples include the Bafoussam (Gouache) landslide in 2019 which killed nearly 47 people and destroyed more than 11 houses (Fallou, 2019; Eyewitnesses); the Limbé landslide in 2001 which killed 24 people, destroyed 120 houses and left more than 2,800 people homeless (Ayonghe et al, 2004); the Mag'haa landslide on 20 July 2003 killed 20 people and several livestock (Kagou Dongmo, 2006; Zogning et al., 2007; Zangmo Tefogoum et al., 2009; Wouatong et al., 2014a); the Koutaba landslide on 11 June 2014 killed 2 people. The Meshi landslide, in the Santa district, occurred on 12 September 1992, resulting in the death of 12 people (Tchotsoua, 1993), the Kekem landslide in October 2007 with one loss of life (Aboubakar et al., 2013). It can thus be seen that beyond human lives, these mass movements affect the environment over long periods of time, the infrastructure, and above all the economy of this part of the country.

The SEBP is often animated by mass movements. There is a high density of people living and practising various activities in areas at risk. Some populations in this area, notably those of Kekem and Santchou, live in low-lying swampy areas. In order to build a shelter, they exploit the soil of the slopes for the purpose of filling in foundations in the marshy area. This exploitation weakens and destabilises the slopes which become vulnerable to mass movement. This is movement due to earthworks (RullenPerchirin, 1987).

Mass movements have been the subject of several scientific works. In addition to these, there is the work of Maquaire et al (2006); Thierry et al (2005); Boyossoro et al (2019); Aggaz and Bali (2017), Che et al (2008); Afungang, (2015); Afungang, (2010); Malet et al (2006). The analysis of mass movement susceptibility in WCHs is still limited to a few localities such as Mount Bamenda..... (Guedjeo et al., 2017; Afungang, 2015; Afungang, 2010). It appears that SEBP, which is characterised by the occurrence of mass movements, has not yet been the subject of a detailed study of such hazards. This study aims to make an inventory of mass movements that occur in order to study their factors and conduct an analysis of the susceptibility of SEBP mass movements. This work is a contribution to the understanding of the factors that govern mass movements in the mountain environments and then assess the associate risks in the $\mathrm{WCH}$.

\section{Geological And Geographical Context}

Volcanic environments in Cameroon are circumscribed within the Cameroon Volcanic Line (CVL). The latter is an $\mathrm{N}^{\circ} 0^{\circ} \mathrm{E}$ oceanic-continental megastructure extending from the Gulf of Guinea to Lake Tchad, $1600 \mathrm{~km}$ long and $100 \mathrm{~km}$ wide. The SEBP is located in the south-continental branch of the CVL; between 
the Bamenda and Manengouba Mountains and more precisely between $5^{\circ} 19^{\prime} 58.8^{\prime \prime}-5^{\circ} 5^{\prime} 16.8^{\prime \prime} \mathrm{N}$ and $9^{\circ} 57^{\prime} 43.2^{\prime \prime}-10^{\circ} 18^{\prime} 10.8^{\prime \prime} \mathrm{E}$ (Fig. 1). This area is the seat of several localities prone to mass movements, notably Santchou, Kekem and Bafang. It covers a total area of about $1030 \mathrm{~km}^{2}$. These climate in the area varies from one area to another. In Santchou, the climate is Cameroonian, while in Kekem it is tropical. This climate is characterised by an alternating dry and rainy season. The average temperature is $22.6^{\circ} \mathrm{C}$ with $197.03 \mathrm{~mm}$ of rain per year. The hydrographic network is sub-dendritic and oriented towards the SW. The soils in the localities are ferralitic, humus-bearing and hydromorphic. These soils are formed on volcanic, plutonic and metamorphic formations including basalts, granites, mylonites and gneisses. The granites, gneisses and mylonites constitute the crystalline base of SEBP. They are covered by basalts which outcrop in domes of varying size.

\section{Methodology}

This mapping work was carried out in several stages:

The exploitation of previous documents allowed us to locate the old movements in the study area and to appreciate the mapping method chosen for the study.

Several field campaigns allowed us to identify and describe vulnerable sites. The aim was to identify the type of mass movement recurrent in the site as well as the signs or indices (fracturing on the slopes, fracturing on the large blocks of hanging rock, the beginnings of landslides).

In the laboratory, satellite images were used to supplement the results of the field inventory. As each vulnerable site was geo-referenced, we drew up a density map of mass movements in the SEBP.

Factors that may influence the occurrence of mass movements in the region were determined and mapped. These factor maps include the slope direction map, the slope curvature map, the stream density map, the stream proximity map, the road proximity map, the geomorphological map, the land use map, the soil map and the geological map. The final susceptibility map was generated by overlaying the different thematic factor maps. This mapping work was carried out by inserting GPS coordinates into our mapping software (ARGIS, Global Mapper and Surfer). The outline of the mass movement susceptibility map is shown in Fig. 2.

\section{Results}

\subsection{Occurrence of mass movements on the SEBP}

Approximately 40 sites favourable for mass movement were mapped in the different localities covering the study area. Fig. 4, 5 and 6 illustrate some of these sites.

\subsection{Study of Susceptibility factors}




\section{- The slope}

Fig. 7 highlights the different slopes that characterise the SEBP. This slope map shows several landscape types. Flat landscapes have slopes between 0 and $7^{\circ}$ and occupy $47.19 \%$ of the total area of the study area. The gently undulating landscapes have slopes between 7 and $13^{\circ}$ and occupy $18.39 \%$ of the area. Undulating landscapes have slopes between 13 and $20^{\circ}$ and occupy $21.49 \%$ of the area. Undulating landscapes have slopes between 20 and $27^{\circ}$ and occupy $7.68 \%$ of the area. Steep landscapes with slopes between 27 and $90^{\circ}$. These slopes occupy $5.25 \%$ of the total area.

\section{- Slope direction}

The slope direction map (Fig. 8) shows several orientation classes. The flat areas occupy $0.09 \%$ of the total area of the study area. North-facing slopes occupy $6.25 \%$, east-facing slopes occupy $9.37 \%$. Southfacing slopes occupy $14.90 \%$. North-east facing slopes occupy $9.41 \%$. South-east facing slopes occupy $13.53 \%$. South-West facing slopes occupy $13.64 \%$. West-facing slopes occupy $12.89 \%$. Slopes facing northwest occupy $14.89 \%$.

\section{- Slope curvature}

The slope curvature map (Fig. 9) shows an area consisting of three levels of curvature. The straight or flat levels are counted as zero slopes and occupy $59.83 \%$, the concave levels are counted as negative slopes and occupy $22.30 \%$ and the convex levels are counted as positive slopes and occupy $17.87 \%$ of the study area.

\section{- The soil}

The soil map (Fig. 10) shows three types of soil. Hydromorphic soils are the soils of low-lying areas. These areas are generally flat, with low-flowing rivers running through them. These soils occupy $41.54 \%$ of the study area and are soils of marshy areas. Humus-bearing soils with little development are the soils found on the slopes. Instability phenomena are most frequent on these types of soil. They represent $34.65 \%$. Ferralitic soils are found at high altitudes. They occupy $23.84 \%$ of the study area and are also the subject of many instabilities.

\section{- Lithology}

The ESPB is mainly made up of granitic, mylonitic and gneissic formations (Fig. 11) which are highly fractured and outcrop in slabs. To these, basaltic and charnokitic formations are added which outcrop in places. Alluvial formations are found in flat areas (Kwekam et al., 2013; Tcheumenak Kouémo et al., 2014; Tcheumenak Kouémo, 2017; Kwekam et al., 2010).

\section{- Land use}

The land use map (Fig. 12) was made from the Google Earth image of the study area. Several types of land use can be observed. Mature forests occupy $42.24 \%$, shrub forests occupy $32.16 \%$, river systems 
occupy $1.68 \%$, cultivated land occupies $8.99 \%$, bare land occupies $12.58 \%$ and habitats occupy $2.31 \%$.

\section{- Geomorphology}

In general, it summarises information on the geometry, arrangement, landforms, nature and structure of surface formations, processes including their duration and rate of formation and the age of landforms. Geomorphological maps reflect aspects of landforms: landforms, correlative surface formations and bedrock. The resulting geomorphological map (Fig. 13) shows three geomorphological units. The plains with altitudes below $982 \mathrm{~m}$ and occupying $41.21 \%$ of the study area, the moderate lands located between 982 and $1319 \mathrm{~m}$ of altitudes and covering $33.17 \%$ of the total area and the highlands which have altitudes above $1319 \mathrm{~m}$ and occupy $25.59 \%$ of the total area of the study area.

\section{- River density}

The river density map (Fig. 14) shows that the density of rivers is not evenly distributed in the area. We have densities ranging from 0 to 21,21 to 54,54 to 84,84 to 113,113 to 144,144 to 183 and 183 to 293 .

n Proximity to watercoursesThe map of proximity to watercourses (Fig. 15) was made by scanning the hydrographic map. The distances obtained were classified into 10 . Distances ranging from 0 to $20 \mathrm{~m}, 20$ to $40 \mathrm{~m}, 40$ to $60 \mathrm{~m}, 60$ to $80 \mathrm{~m}, 80$ to $100 \mathrm{~m}, 100$ to $120 \mathrm{~m}$ and those above $120 \mathrm{~m}$. All distances above $120 \mathrm{~m}$ were considered to have no influence on mass movements and occupied the highest percentage $(38 \%)$.

$\mathrm{n}$ Proximity to roadsThe road proximity map (Fig. 16) shows distances grouped into 6 classes. Distances ranging from 0 to $10 \mathrm{~m}, 10$ to $20 \mathrm{~m}, 20$ to $30 \mathrm{~m}, 30$ to $40 \mathrm{~m}, 40$ to $50 \mathrm{~m}$ and distances above $50 \mathrm{~m}$. The distribution of values is even in the distances between 0 and $50 \mathrm{~m}$.

\subsection{Assessment of susceptibility to mass movement}

The assessment of the susceptibility is done through the creation of a mass movement susceptibility map. The susceptibility map (Fig. 17) shows four classes which reflect four different levels of susceptibility spread over the whole study area defined as follows: low susceptibility, moderate susceptibility, high susceptibility and very high susceptibility. This map should integrate the spatial dimension and the probability of occurrence of mass movements in a given time period. Although these elements are assumed to be independent (Guzzetti, 2005). These susceptibility classes are defined by susceptibility indices ranging from 0.099 to 0.627 (Tab.1). The susceptibility indices are the attributes related to the different susceptibility levels and are created in the database when combining them in the GIS. Therefore, the higher the susceptibility index, the more sensitive the area is to mass movements (Boyossoro et al., 2019).

The mass movement susceptibility map with favourable sites (Fig. 18) locates the vulnerable sites on the susceptibility map. It can be seen that all the different risk levels contain areas vulnerable to one type of 
mass movement. One subsidence site is noted in the flat area. Rockfall and landslide sites are more present in the medium, high and very high risk areas.

Table 1 shows that $16.95 \%$ represent low susceptibility areas. These are areas with a low probability of occurrence of a mass movement. These are low slope areas that can be inhabited by people and several other activities can be carried out there. $43.39 \%$ represents moderate susceptibility areas. Moderate susceptibility areas are areas that have a medium probability of occurrence of a mass movement. The slope here is the predominant factor and is not very steep. $29.77 \%$ represents the high susceptibility zones. An area like this has a high probability of occurrence. They are often not very suitable for human activities. 9.89\% represents very high susceptibility areas. The very high susceptibility zones show a very high probability of occurrence of mass movements. In the very high risk areas there are very steep slopes between 27 and $90^{\circ}$.

Table 1: Repartition of susceptibility indices

\begin{tabular}{|lll|}
\hline Classes & Susceptibility indices & Percentages (\%) \\
\hline Low & $0.099-0.265$ & 16.95 \\
\hline Moderate & $0.265-0.364$ & 43.39 \\
\hline High & $0.364-0.463$ & 29.77 \\
\hline Very high & $0.463-0.627$ & 9.89 \\
\hline
\end{tabular}

\section{Discussion}

The CVL in general, the WCHs in particular and the ESPB are extremely favourable areas for mass movements, with a strong increase in damage (Zogning et al., 2007). Heavy rainfall in August, September and October, rapid and uncontrolled urbanisation, over-exploitation of slopes and deforestation are the main causes of mass movements in the region (Aboubakar et al., 2013). Landslides are the most recurrent mass movements. Subsidence is also caused by extreme rainfall. Boulder falls are caused by bushfires that create cracks in the rocks. In the Bamenda Mountains, landslides are also caused by heavy rainfall associated with human activities such as uncontrolled road construction, vehicle vibrations and uncontrolled agricultural practices (Guedjeo et al., 2013; Afugang and Bateira, 2015; Zangmo Tefogoum et al., 2016; Guedjeo et al., 2017). Work carried out by several authors in localities such as Limbé, Bambouto, Kekem, Mag'haa, Echiock-Santchou along the CVL (Ayonghe et al., 2004; Zangmo Tefogoum et al., 2009; Aboubakar, 2010; Kagou Dongmo, 2006; Ndonbou, 2018) has shown that, in general, anthropogenic activities significantly increase the occurrence of mass movements.

The various areas prone to mass movements in the region were delineated and mapped. The resulting susceptibility map shows the different levels of probability. Low probability areas occupy $16.95 \%$ of the region, medium probability areas occupy $43.39 \%$, high probability areas occupy $29.77 \%$ and very high probability areas occupy $9.89 \%$. A susceptibility map with the vulnerable sites has been produced. On this 
map, it can be seen that the majority of landslides are found in the high probability areas. On the other hand, on the Bamenda Mountains, the majority of landslides are located on the very high probability areas (Guedjeo et al, 2017; Guedjeo, 2019). This difference may be due to the type of environment as the Bamenda Mountains have a purely volcanic environment whereas the ESPB has a plutonic, metamorphic and sedimentary environment. The landslide density map made by Poueme Djeuyap (2018) in the Monte Mario area NW of Rome (Central Italy) shows that the majority of landslide niches (90\%) are located in very high risk areas. The susceptibility indices obtained are quite high especially for the very high classes. This could be due to the fact that these are areas with a high probability of occurrence to mass movements. The work of Boyossoro et al (2019) shows lower susceptibility index values than in the SEBP. This difference would be linked to the geomorphology of the regions studied.

Cameroon, because of its mountainous landscapes (CVL), is really affected by mass movements. It is for this reason that the mapping of these mass movements has always been a major challenge because of the lack of knowledge on the issue. However, over the last few decades, significant progress has been made in improving mapping techniques. Some of the techniques used have proven to be successful. The method based on raster data to build a susceptibility model has been implemented by Che et al. (2012) in the Limbe region. Bivariate and multivariate models were implemented by Afungang (2015) and Guedjeo et al. (2017) on the Bamenda Mountains. Thierry et al (2008) implemented the weighted index method in the Mabeta region (Mount Cameroon). These methods have been used in other countries, notably in the assessment and GIS mapping of landslide risk in the Alps in southern France (Maquaire et al., 2006; Malet et al., 2006).

Assessing the probability of mass movements always involves conditioning factors. Whatever method is used, it requires a prior identification of the influencing factors. Each factor is involved in its own way in this occurrence and their involvement may vary from one site to another or from one region to another. Factors such as slope, soil, proximity to roads, land use and geology are essential in assessing the risk of landslides. The majority of landslides, for example, occur on steep slopes; the soil is the material that is mobilised; there is generally a strong tendency for landslides to occur on the edges of roads; uncontrolled land use, over-exploitation of slopes in search of fill material, deforestation and uncontrolled agricultural practices weaken and predispose the slopes to potential landslides. Fractured and highly weathered rock on slopes also poses a significant threat of boulder falls. The factors are not always the same in all regions affected by mass movements. In the Man region of Ivoiry Coast, in addition to slope, land use, fracture density, rainfall and weathering thickness are mapped (Boyossoro et al., 2019). It is equally important to know that the presence of conditioning factors is not a sine qua non condition for the occurrence of mass movement. For a slip to occur, for example, it must be triggered. Most of the triggers for landslides along the CVL are earthquakes, heavy rainfall and gravity (Ayonghe, 2004; Afungang, 2015). On the SEBP, the landslides recorded were triggered by the rains that occurred in the area the day before. The Kekem landslide, for example, was triggered by heavy rainfall the day before the landslide. Similarly, those of Ntiengue, Echiock-Santchou, Njungo and Essoh-Attah were triggered after heavy rainfall (Aboubakar et al., 2014; Ndonbou, 2018; Nchadji, 2018; Djiague Tabagan, 2018; Aboubakar, 2010). 
In general, mass movements in tropical areas are influenced by several climatic and environmental factors. It is equally important to know that these mass movements are most influenced by the slope and as well as the heavy rains associated with the nature of the soil.

\section{Conclusion}

The SEBP is a region with a high risk of mass movement. Several factors influence the occurrence of mass movement in this region. Ten factors (slope, slope orientation, curvature, stream density, proximity to roads, geomorphology, proximity to streams, lithology and land use and soil) were studied and mapped. Slope is one of the most important factors influencing slope instability in this region. The method of superimposing the factors allowed us to produce the susceptibility map for mass movements in this region. This map shows that there are $16.95 \%$ of low probability areas, $43.39 \%$ of moderate probability areas, $29.77 \%$ of high probability areas and $9.89 \%$ of very high probability areas. Landslides are a major hazard in the study area. This work provides decision-makers with important data useful for the development of this area. In addition, this study can be applied to other densely populated areas of the $\mathrm{WCH}$ that are prone to mass movements.

\section{References}

Aboubakar B. Kagou Dongmo A. Nkouathio D.G. Ngapgue F. (2013). Instabilité des terrains dans les Haute Terres de l'Ouest Cameroun: Caractérisation géologique et géotechnique du glissement de terrain de Kekem. Bulletin de I'Institut Scientifique,Rabat, Section Sciences de la terre, $20, n^{\circ} 35,39-51 p$.

Afungang R. and Bateira C., (2016). Statistical modelling of extreme rainfall, return periods and associated hazards in the Bamenda Mountain, NW Cameroon. Revista de Geografia e Ordenamento do Territorio (GOT), n.o 9 (junho). Centro de Estudos de Geografiae Ordenamento do Territorio, p.5-19

Aggaz H, et Bali M. (2017). Cartographie Géotechnique, des Risques de Glissements de terrain de la ville de Bejaia (ALGERIE). Memoire fin d'etude master 2 Université A. MIRA Bejaia.

Ayonghe S. N., Ntasin E. B., Samalang P., Suh C. E. (2004). The June 27, 2001 landslide on volcanic cones in Limbe, Mount Cameroon, West Africa. Journal of African Earth Sciences 39 (2004)435 439.

Bétard F. Delbart N. Pie C. (2014). Cartographie de la susceptibilité aux glissements de terrain dans la région de Nova Friburgo (État de Rio de Janeiro, Brésil). Une étape vers l'évaluation et la gestion du risque. Bulletin de l'association de journals. Openedition.org 2014. 20p

Boyossoro H. K., Kan J K., Sika B., Gabriel E. A., Vami H. N., B., Assa Y. (2019). Utilisation des SIS et de la télédétection pour la Cartographie de la susceptibilité aux mouvements d'instabilité de versant dans l'Ouest Montagneux de la Côte d’Ivoire. Revue Française de photogrammétrie et de Télédétection. Vol. 1 $N^{\circ} 221, p p$ 3-21 
Brilly M., Mikoš M., Kobold M. (2002). Catastrophe caused by debirs flow in the village of Log Pod Mangartom in autumn 2000. Mediterranean storms: proceedings of the $3^{\text {rd }}$ ESG Plinius conference,Bafa Sardinia, Italy, October 1-3, 2001, pp. 367-370.

Cardinali M, Carrara A., Guzzetti F, Reichenbach P. (2002): Landslide hazard map for the Upper Tiber River basin. CNR, Gruppo Nazionale per la Difesa dalle Catastrofi Idrogeologiche, Publication n. 2116

Carrara, A., Cardinali, M., Detti, R., Guzzetti, F., Pasqui, V., et Reichenbach, P. (1991). GIS techniques and statistical models in evaluating landslide hazard. Earth surface processes and landforms, 16(5), 427$445 p$.

Che, V. B., Kervyn, M., Ernst, G., Trefois, P., Ayonghe, S., Jacobs, P., Suh, C. E. (2011). Systematic documentation of landslide events in Limber area (Mt Cameroon Volcano, SW Cameroon): geometry, controlling, and triggering factors. Natural Hazards, 59(1), 47, 74p.

Che, V. B., Kervyn, M., Suh, C., Fontijn, K., Ernst, G. G., del Marmol, M.A., \& Jacobs, P. (2012). Landslide susceptibility assessment in Limbe (SW Cameroon): A field calibrated seed cell and information value method. Catena, 92, 83-98p

El Fahchouch N. A., Brahim A. L., Raji O. et Khouakhi A. (2015). Apport du SIG et de la télédétection dans la modélisation spatiale de la susceptibilité aux mouvements de terrain dans la région d'Al Hoceima, Rif Oriental, Maroc. Afrique Science 11(2), pp.44 - 57

Fallou (2019). Cameroun: reprise des fouilles sur le site du glissement de terrain à Bafoussam. Vonews Afrique, www. vonews.net,(access on November 4th, 2019).

Flageollet J.-C., Maquaire O., Martin B., Weber D., (1999). Landslides and climatic conditions in the Barcelonnette and Vars Basins Southern French Alps, France. Geomorphology, vol. 30, p.65-78.

Guedjeo C. S. Kagou Dongmo A., Wotchoko P. Nkouathio D. G.Chenyi M. L. Wilson B., Kamgang K.V. (2017). Landslide Susceptibility Mapping and Risk Assessment on the Bamenda Mountain Cameroon Volcanic Line. Journal of Geosciences and Geomatic $\quad$ 2017, vol. 5 n 4 173185.

Guedjeo C. S., Kagou Dongmo A., Ngapgue F., Nkouathio D. G., Zangmo Tefogoum G., Gountié Dedzo M., Nono A., (2013). Natural hazards along the Bamenda escarpment and its environs: The case of landslide, rock fall and flood risks (Cameroon volcanic line, North-West Region). Glo. Adv. Res. J. Geol. Min. Vol. 2(1) pp. 015-026

Kagou Dongmo A. Wandji P. Pouclet A. Nkouathio D. G.Tchoua F.M. (2005). Le mont Manengouba (ligne du Cameroun), un volcan bénéfique, mais potentiellement dangereux, typologie des aléas et évaluation des risques naturels associés. Afr. Géosci.Review, 109 p. 
Kwékam M., Leogeois J P., Njonfang E., Affaton p. Hartman G., Tchoua F. (2010) nature origin and significance of the Pan-African highk calc-alkaline Fomopea plutonic complex in the central African fold belt (Cameroun). Journal of African Earth Sciences, Vol 57 pp 79-95

Malet, J.P., Van Asch, Th.W.J., Van Beek, R., Maquaire, O. (2006). Forecasting the behaviour of complex landslides with a spatially distributed hydrological model. Natural Hazards and Earth System ScieTnces, 2005-5, 1-15.

Nagarajan R., Roy A., Kumar R., Mukherjee A., Khire M. (2000): Landslide susceptibility mapping base on terrain and climate factors for tropical monsoon regions. Bulletin of Engineering Geology and Environment, 58: 275-287.

Olivier M., Yannick T., Jean-Philippe M., Anne P.(2006). Évaluation et cartographie par SIG du risque 'glissement de terrain'. Application aux Alpes du Sud. Interactions Nature-Société Analyse et Modèles. UMR CNRS 6554 LETG, La Baule 2006

Rullen-Perchirin. (1987). Les mouvements de masse dans le bassin-versant du Rhumel constantinois: essai méthodologique. Travaux de I'Institut de Géographie de Reims Année 1987 69-72 pp. 151171

Tcheumenak kouémo, J., Njanko, T., Kwekam, M., Naba, S., Bella Nke, B.E.,Yakeu Sandjo, F.,Fozing E. M., Njonfang E. (2014). Kinematic evolution of the Fodjomekwet-Fotouni Shear Zone (WestCameroon): Implications for emplacement of the Fomopéa and Bandja plutons. Journal of African Earth Sciences 99 (2014) 261-275

Tchindjang M. (2012). Paradoxes et risques dans les hautes terres camerounaises: multifonctionnalité naturelle et sous valorisation humaine. HDR, Vol. 3 Université de Paris 7, 266p

Tchindjang M. (2013). Mapping of natural hazards in Cameroon. Conference paper held at the International cartographic conference Dublin, Germany. Géographe environnementaliste,Département de Géographie, Univ. Yaoundé I. Po Box 30464 Yaoundé. 13p

Tchotsoua M., (1993) : Risque d'éboulement de bloc rocheux sur les versants des monts orientaux du massif de Yaoundé : cas des monts Oyom-Abang et Mvog-Bétsi., Rvg. De Géogr. du Cam., pp.21-31.

Thierry, P., Stieltjes, L., Kouokam, E., Nguéya, P., \& Salley, P. M. (2008). Multi-hazard risk mapping and assessment on an active volcano: the GRINP project at Mount Cameroon. Natural Hazards, 45(3), 429-456p.

Wouatong, A., Medjo, E., Nankam, M., Beyala, K., \& Ekodeck, G. (2014a). Mineralogy, geochemistry and geotechnical characteristics of Magha landslides in the Bambouto Caldera, West Cameroon. Journal of Civil Engineering and Science, 3(1), 36-49p.

Zangmo Tefogoum G., Kagou Dongmo A., Nkouathio D. Wandji P. (2009). Typology of natural hazard and assessment of associated risk in the Mont Bambouto caldera (Cameroun line West Cameroon). Acta 
geologica sinica, 83, 5, 1008-1016.

Zogning A. Tiofack 0. (2004). Landslide assessment and prevention of futur risk, Mount Bambouto, Cameroun. Parbleu Technilogie sinc. Siteweb : http://WWW.treemail.nl/privateers/Cameroun/.

\section{Figures}

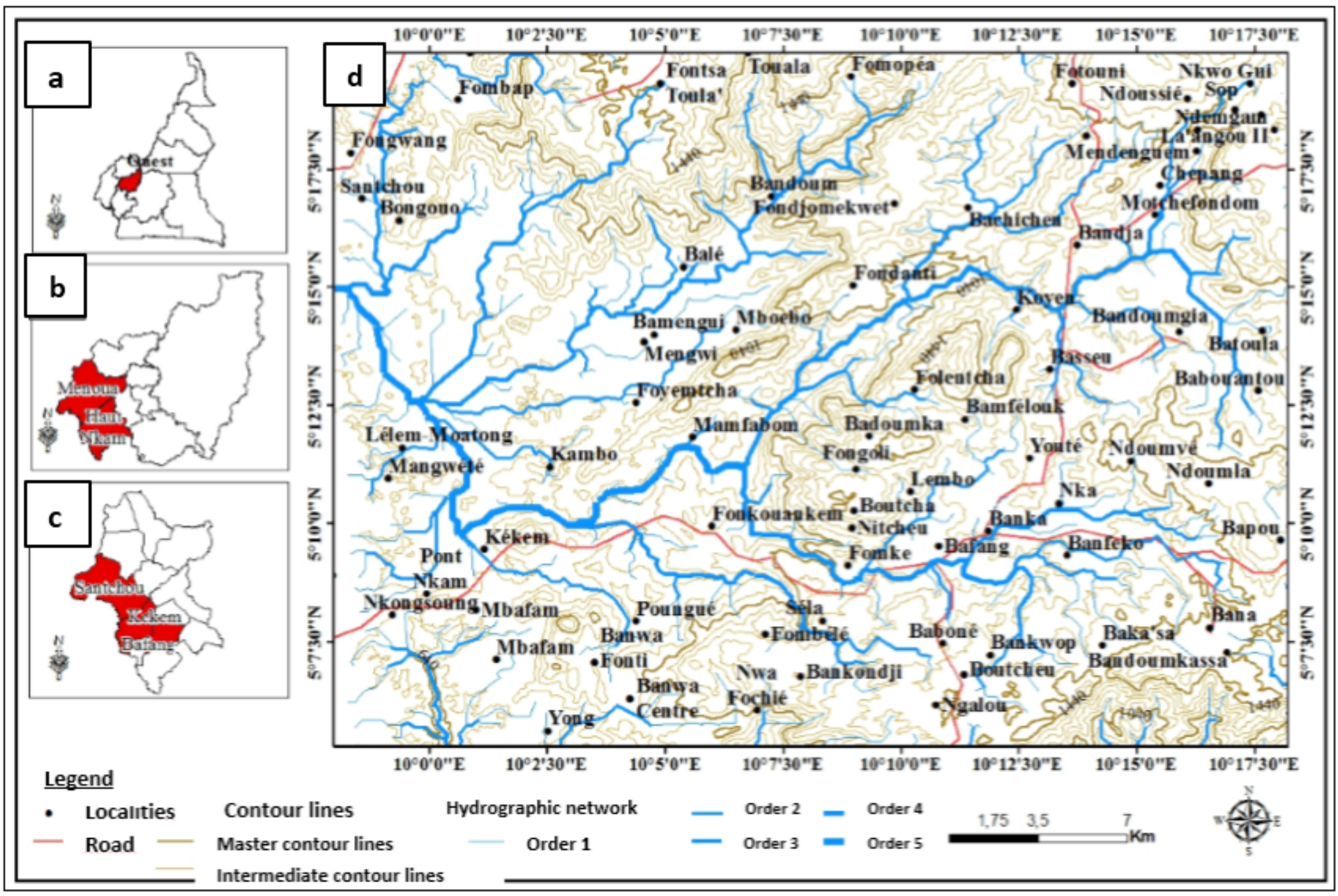

Figure 1

Location map of SEPB a) Cameroon b) Western region c) Localities in the SEBP d) SEPB 


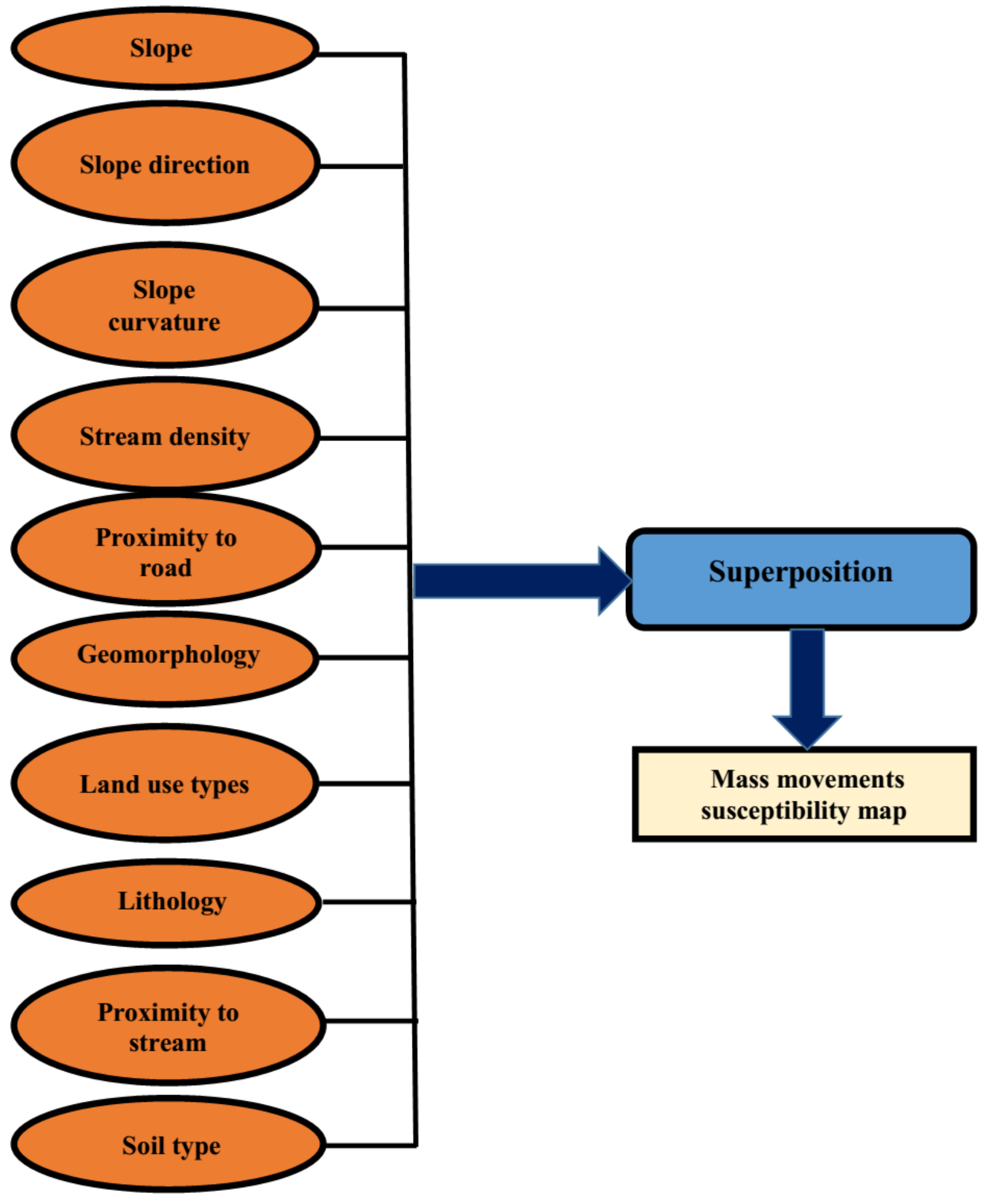

Figure 2

Outline of the mass movement susceptibility map 


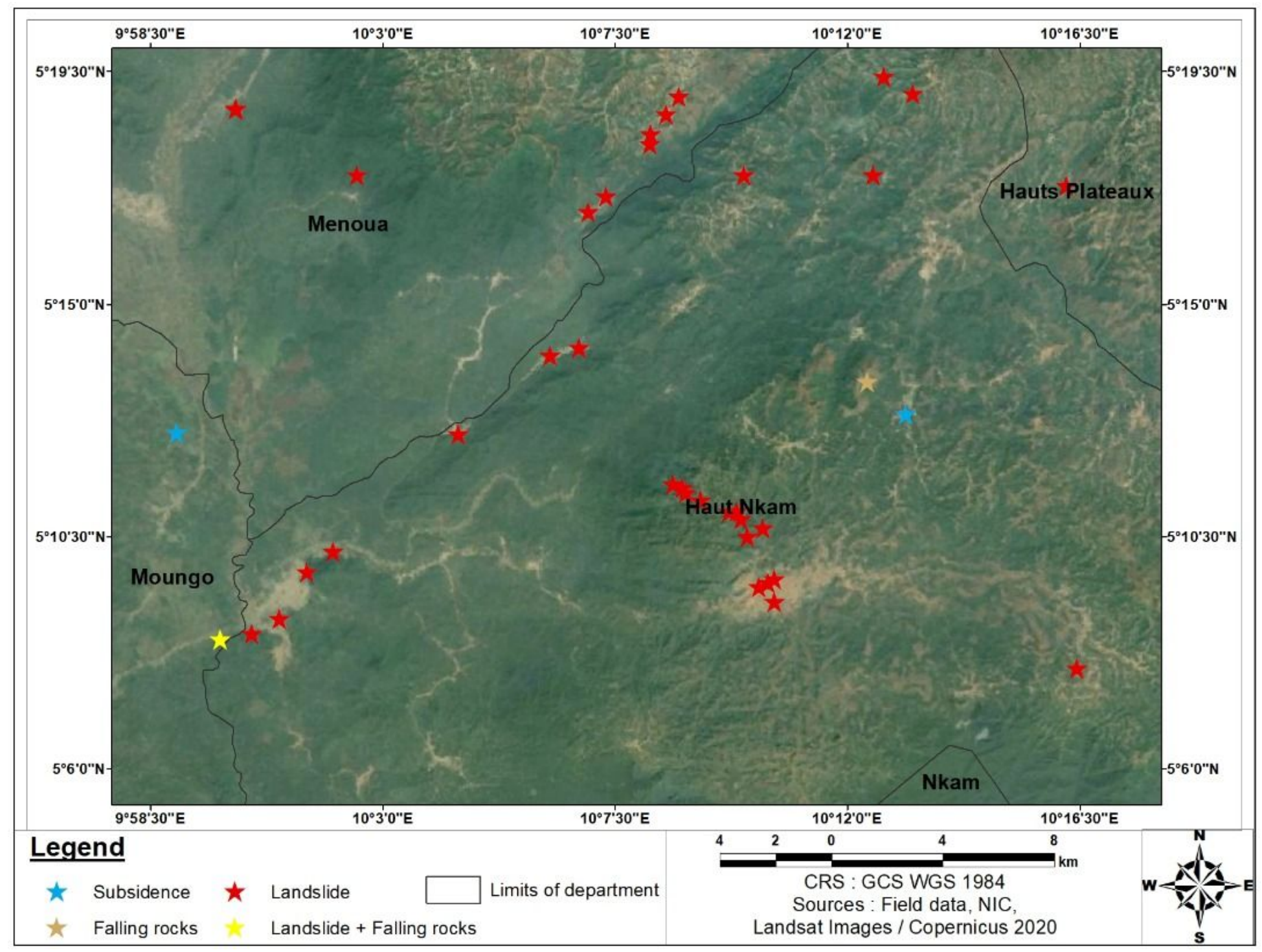

\section{Figure 3}

Mass movement density map of the SEBP (extracted from Google Earth) 

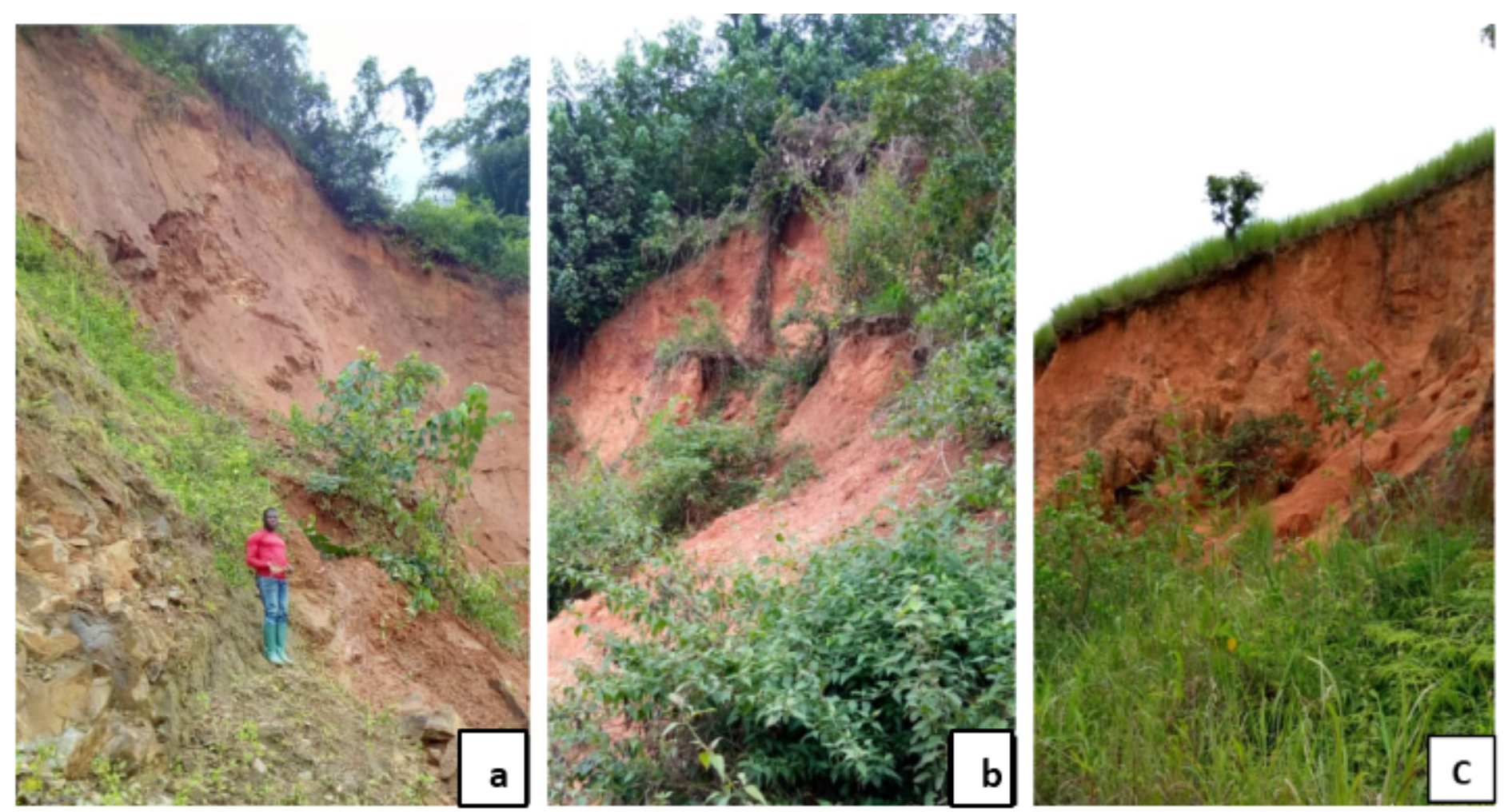

\section{Figure 4}

Images of some landslides in the SEBP a) Santchou; b) Bandoum; c) Fomopea 

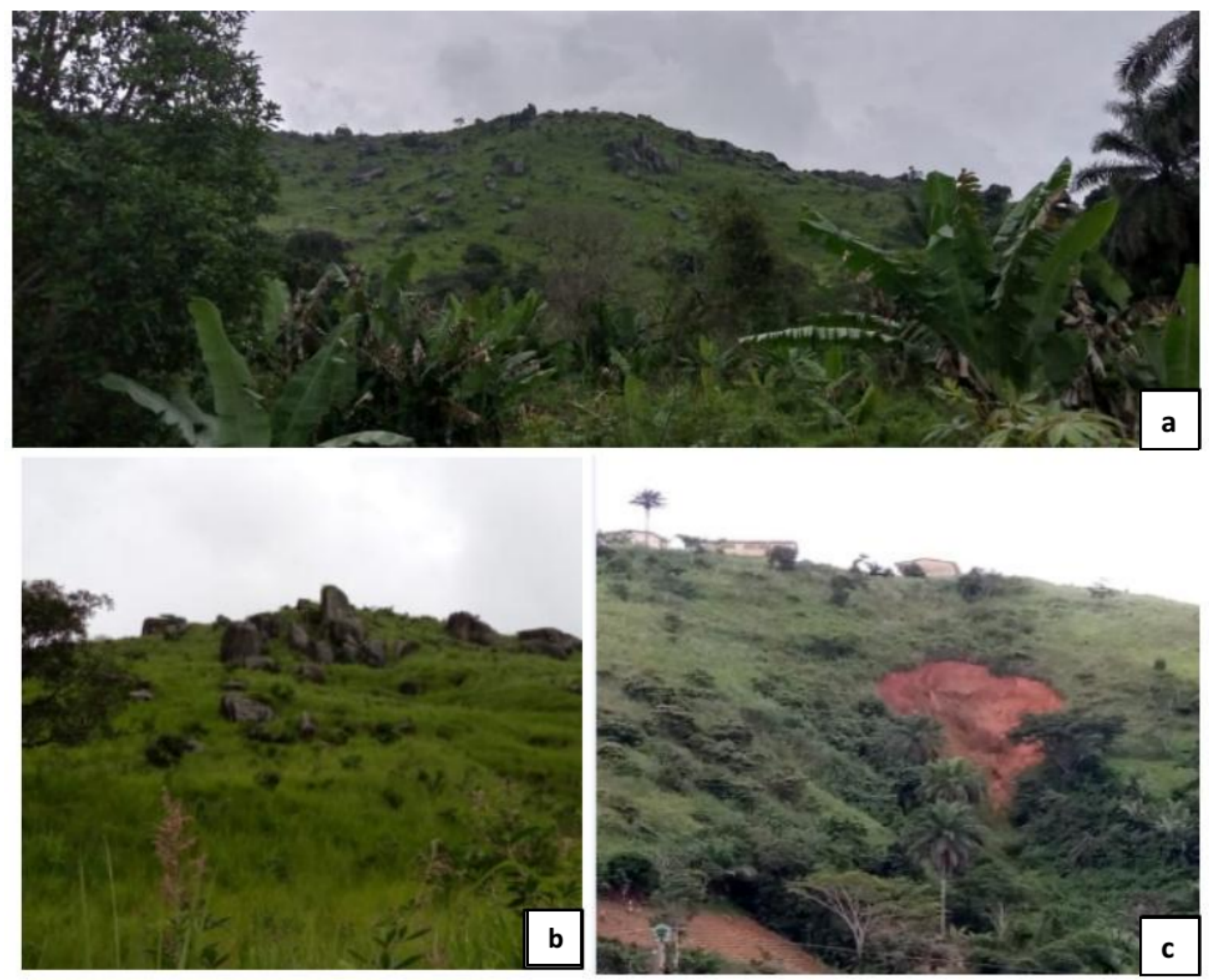

\section{Figure 5}

Images of mass movements in some SEBP area. a and b) Block falls in Basseu; c) Landslide in Fomopéa 

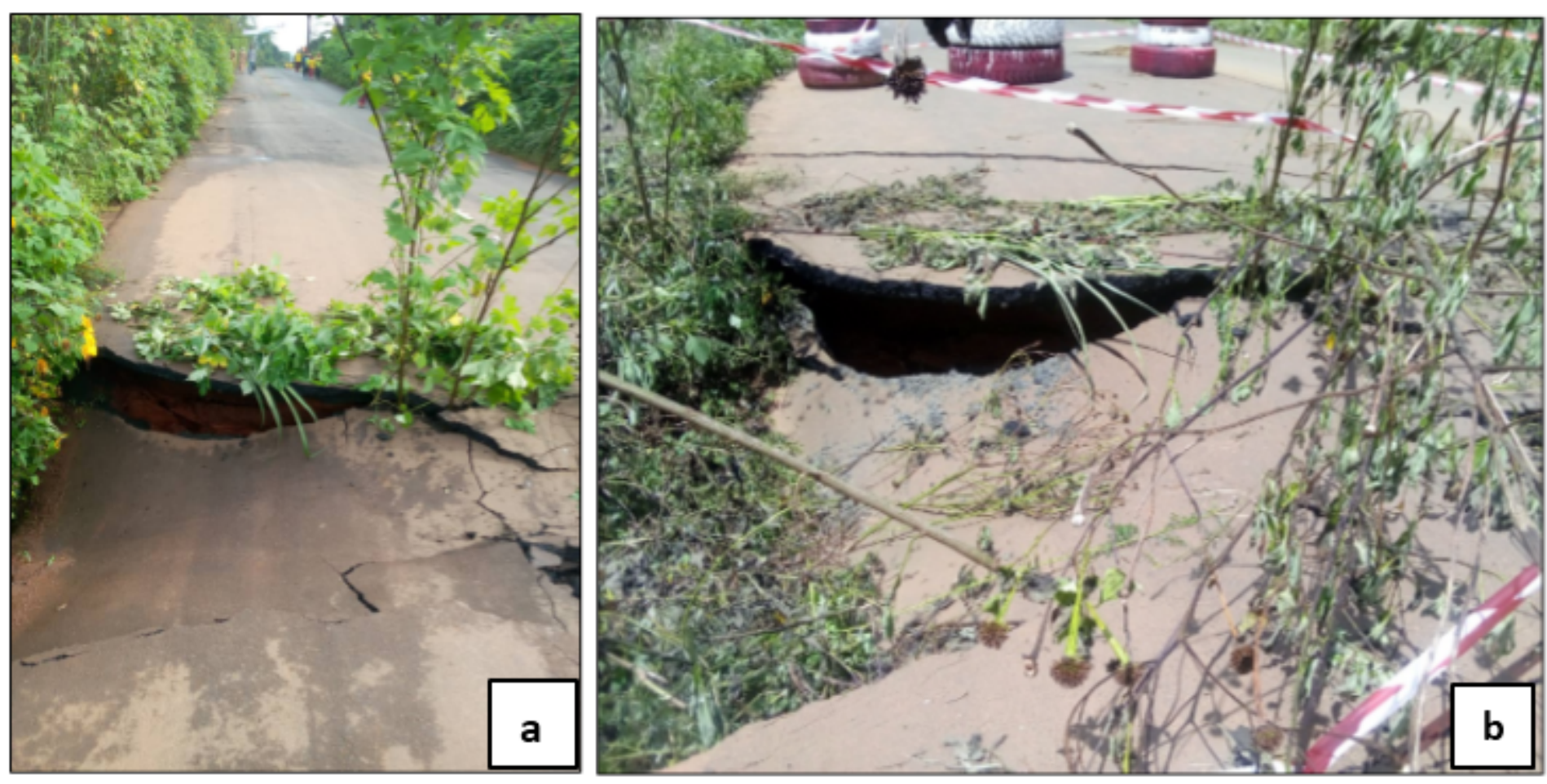

Figure 6

Images of subsidence-type mass movement in the SEBP. a and b. Bandja by Bafang 


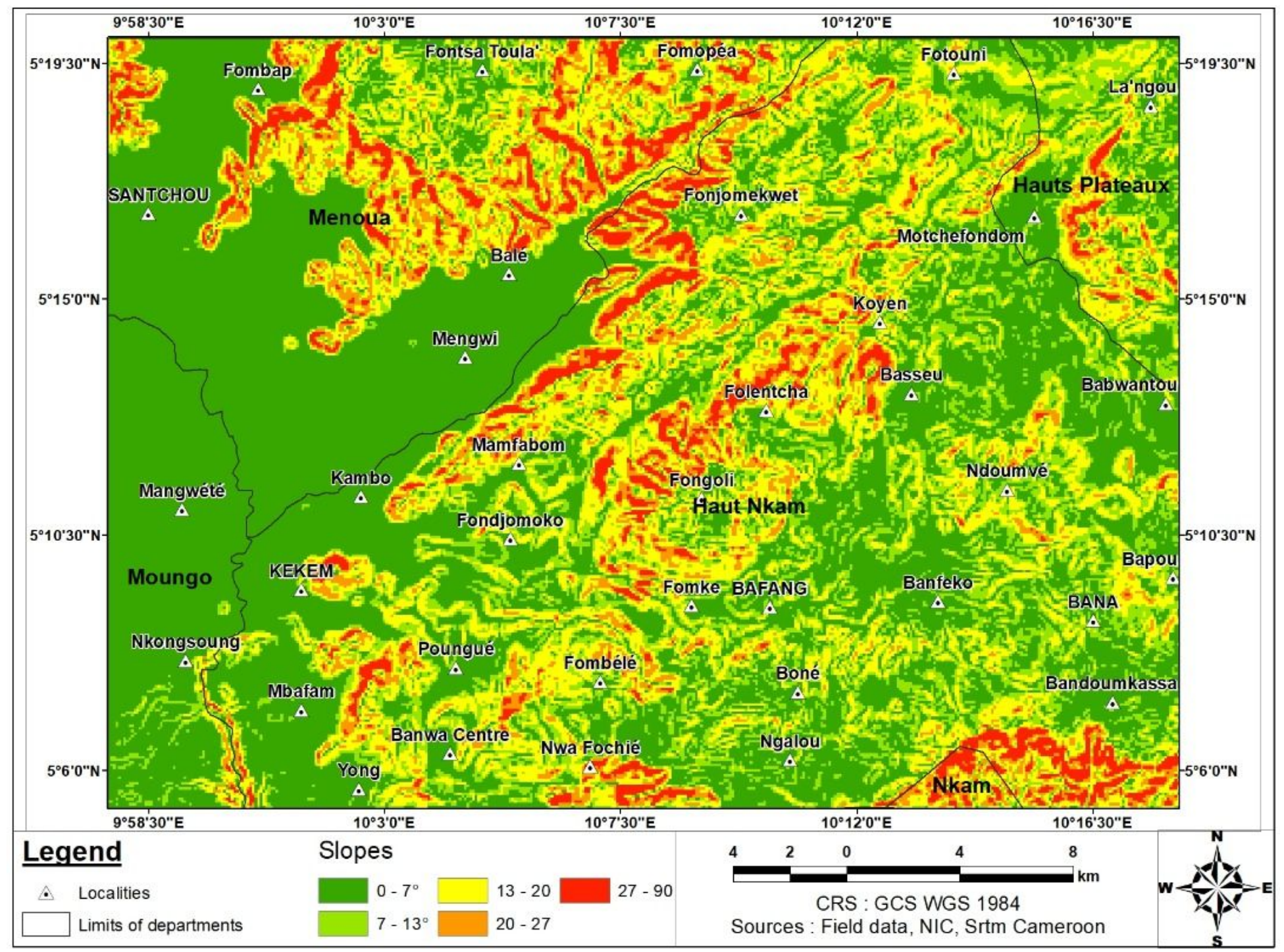

\section{Figure 7}

Map of slopes in the SEBP 


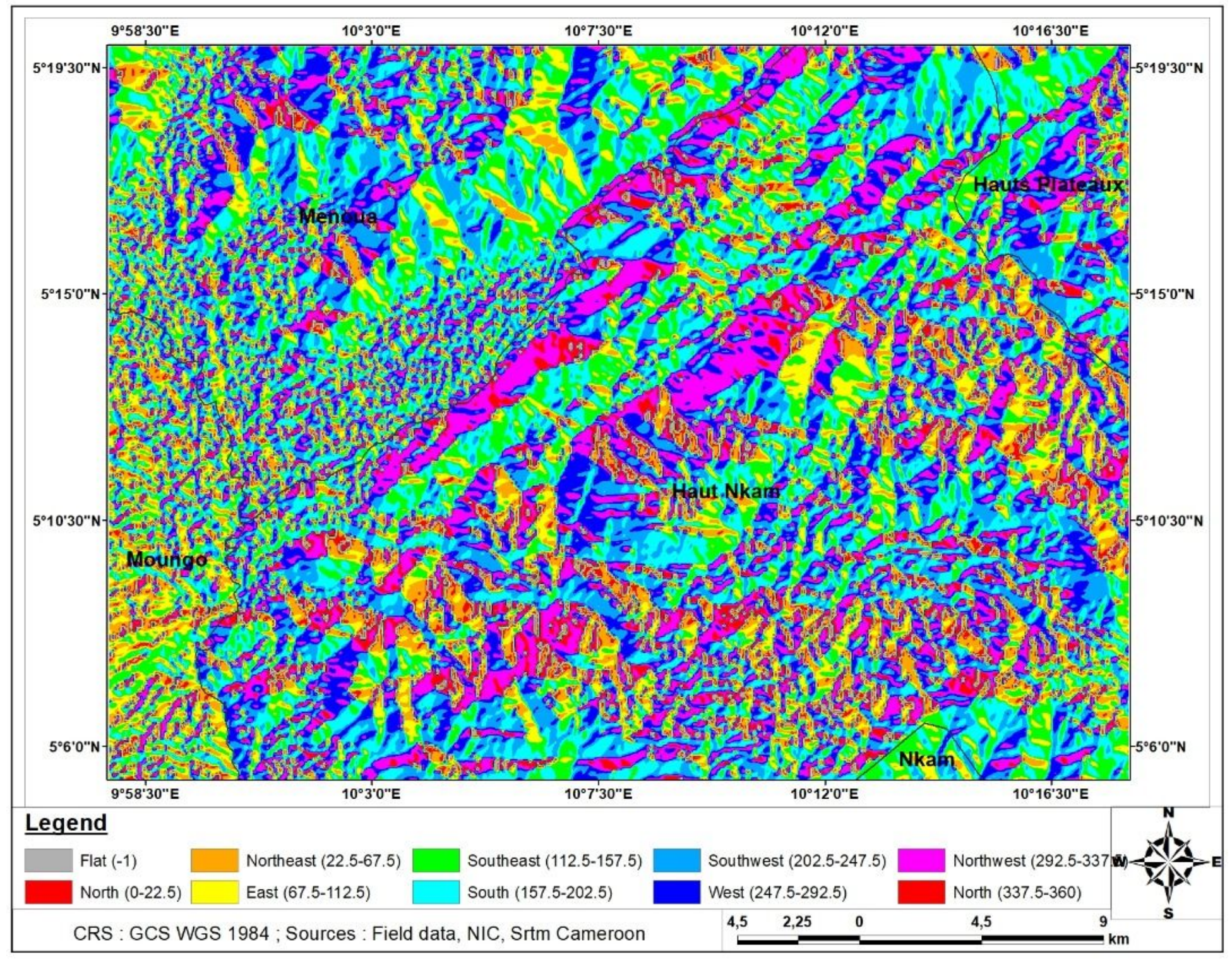

Figure 8

Slope direction map of the SEBP 


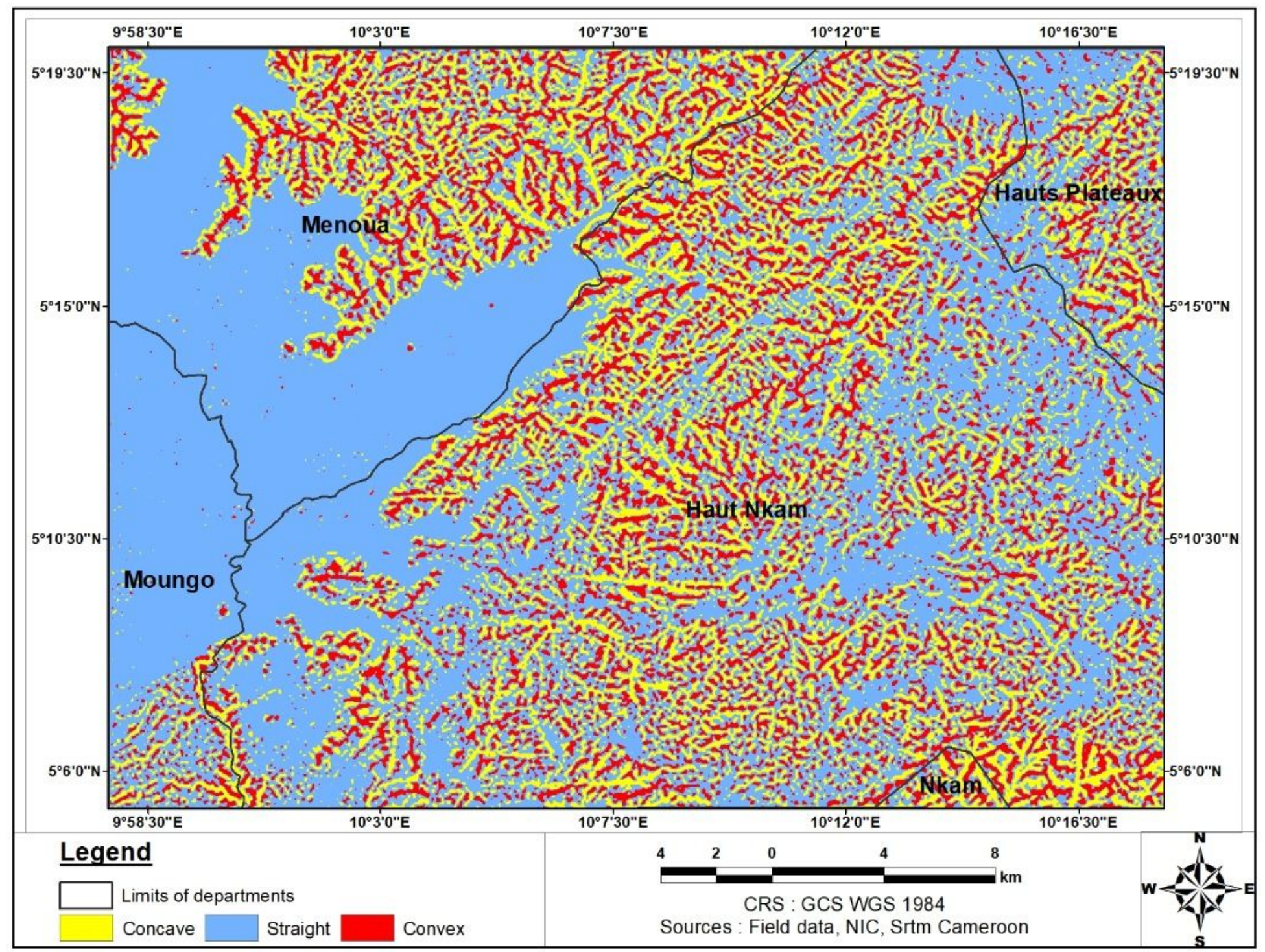

Figure 9

Map of slope curvature of the SEBP 


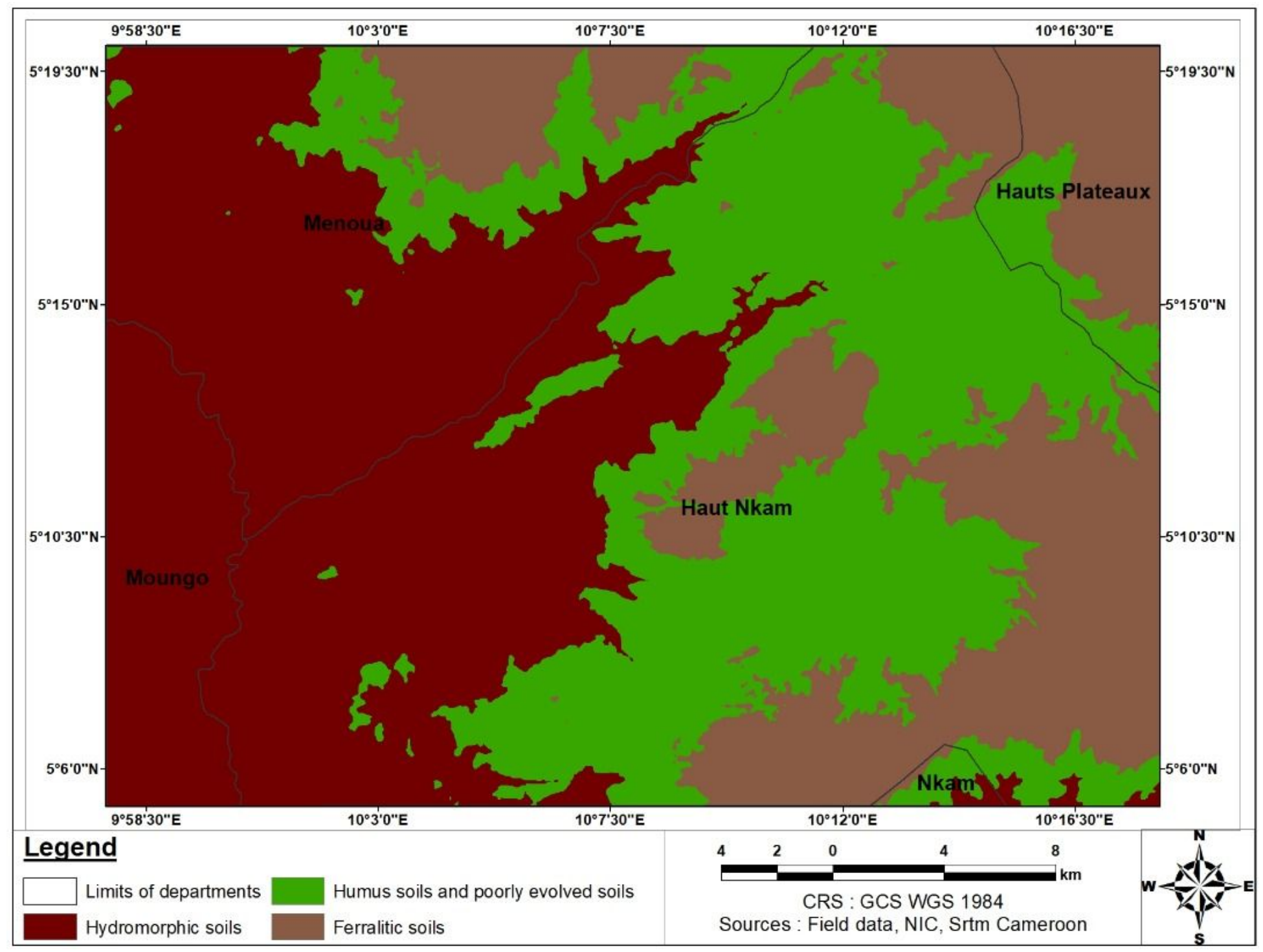

Figure 10

Soil map of the SEBP 


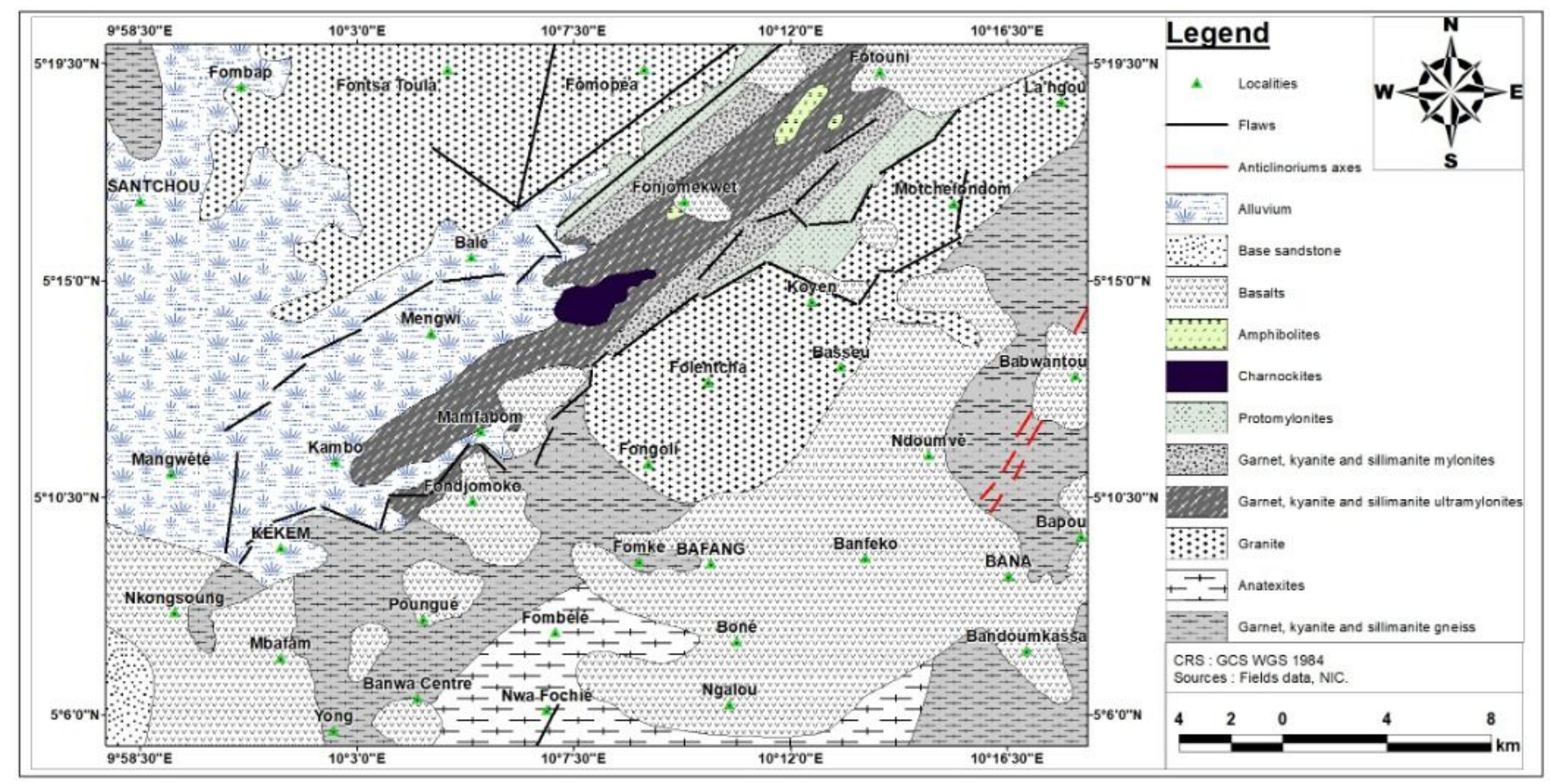

Figure 11

Geological map of the SEBP modified after Dumort, 1968; Tcheumenak Kouemo et al., 2014 ; Kwékam et al., 2013 ; Tcheumenak Kouemo, 2017 


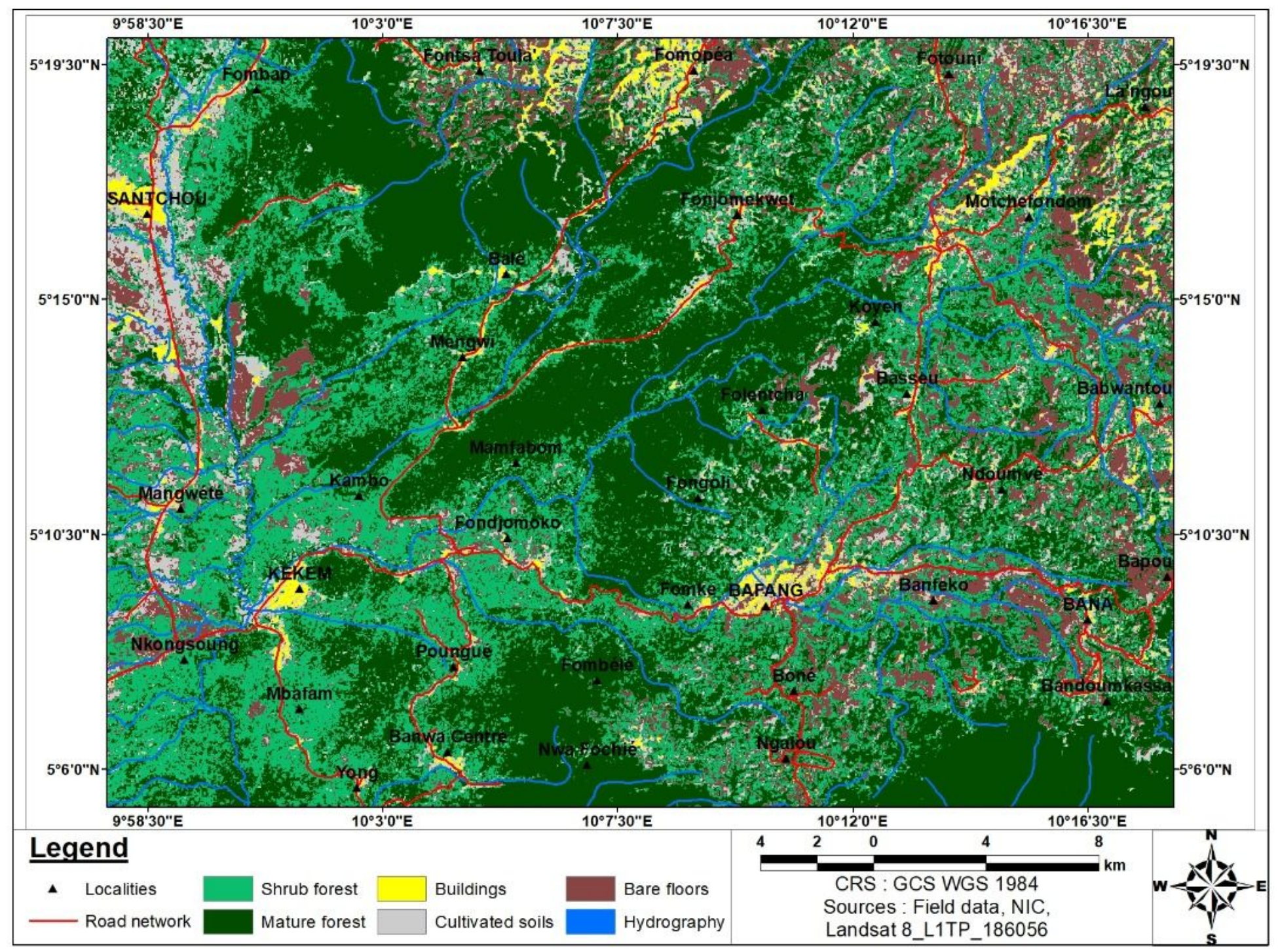

\section{Figure 12}

Land use map of the SEBP 


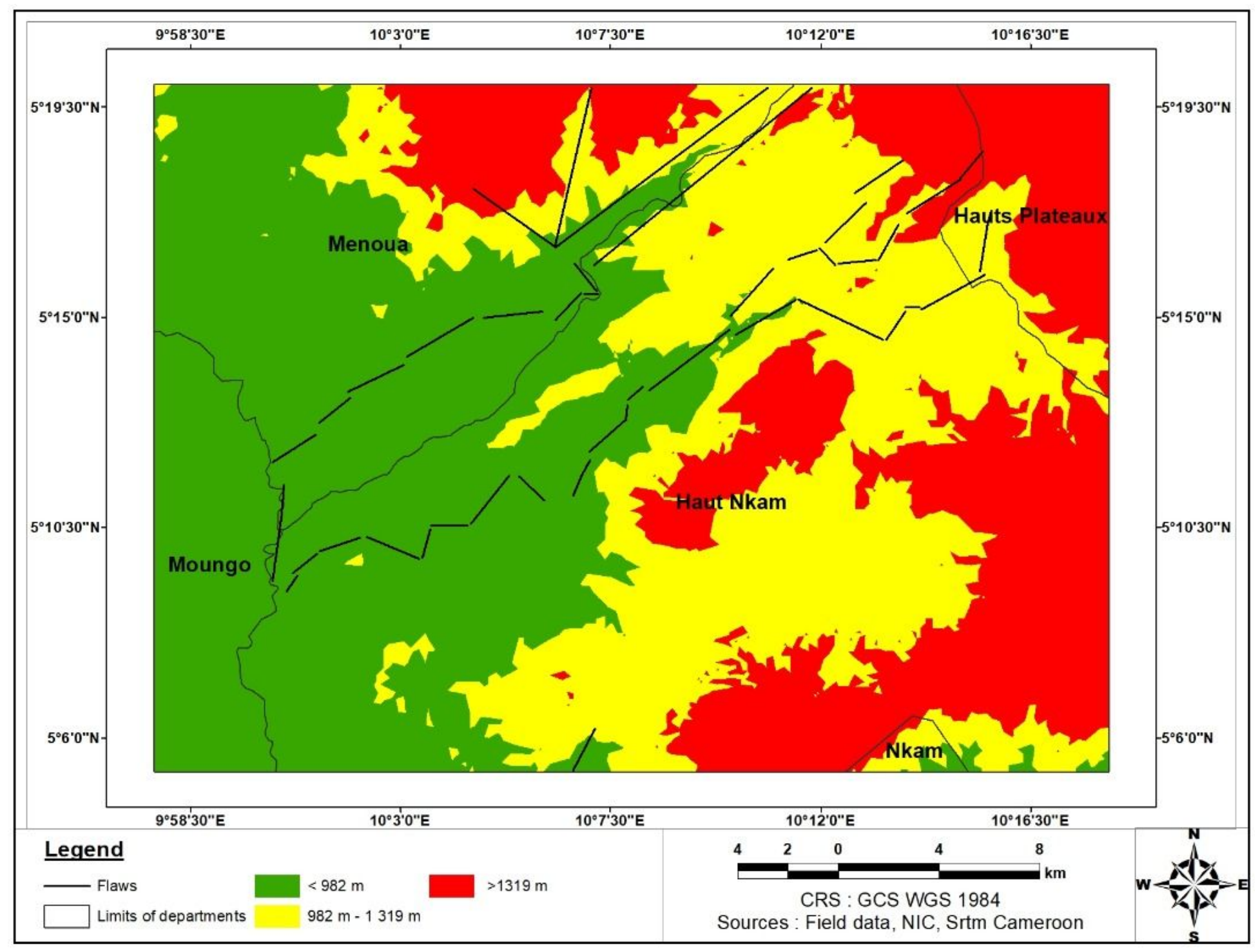

Figure 13

Geomorphological map of the SEBP 


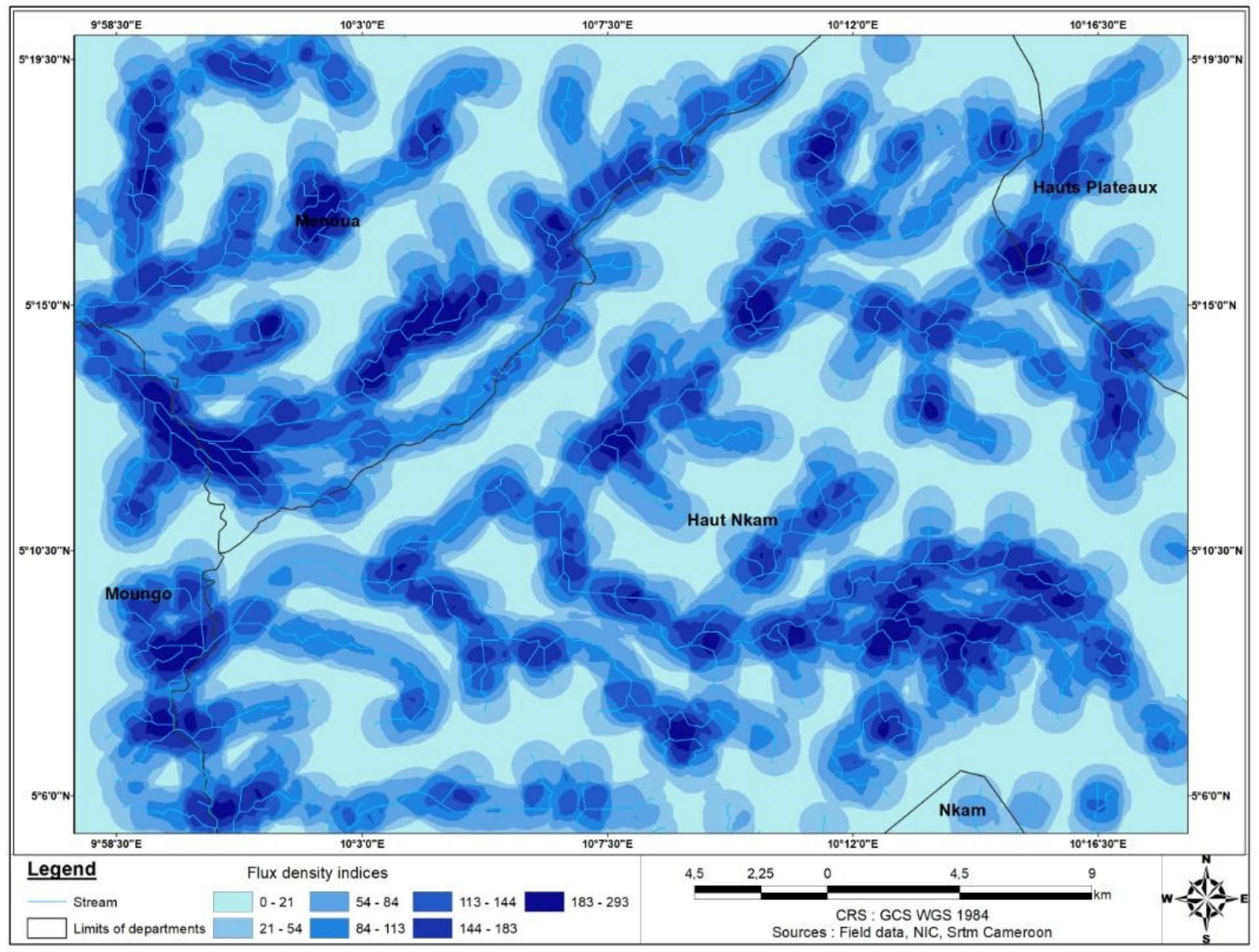

Figure 14

River density map of the SEBP 


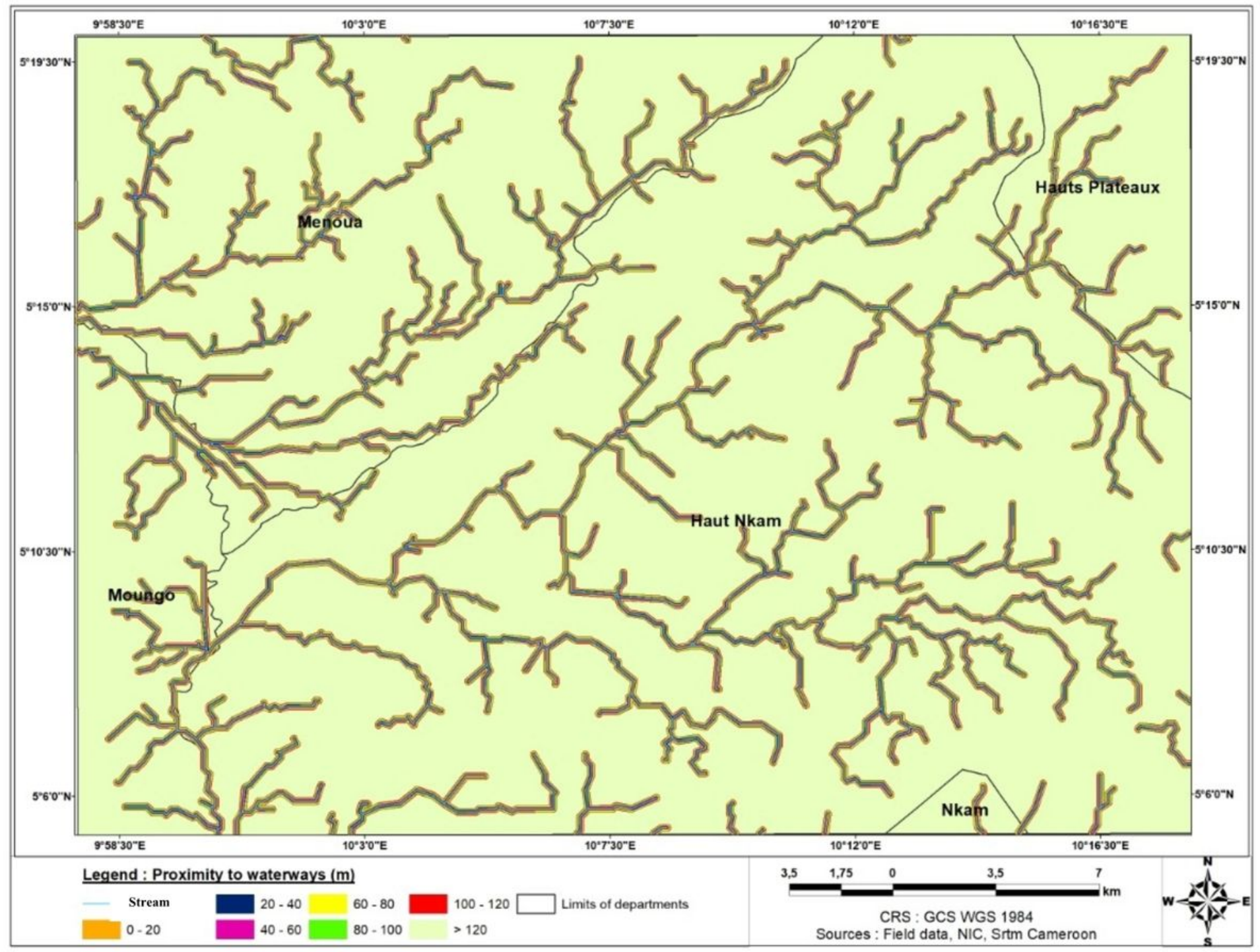

Figure 15

Proximity map of watercourses in the SEBP 


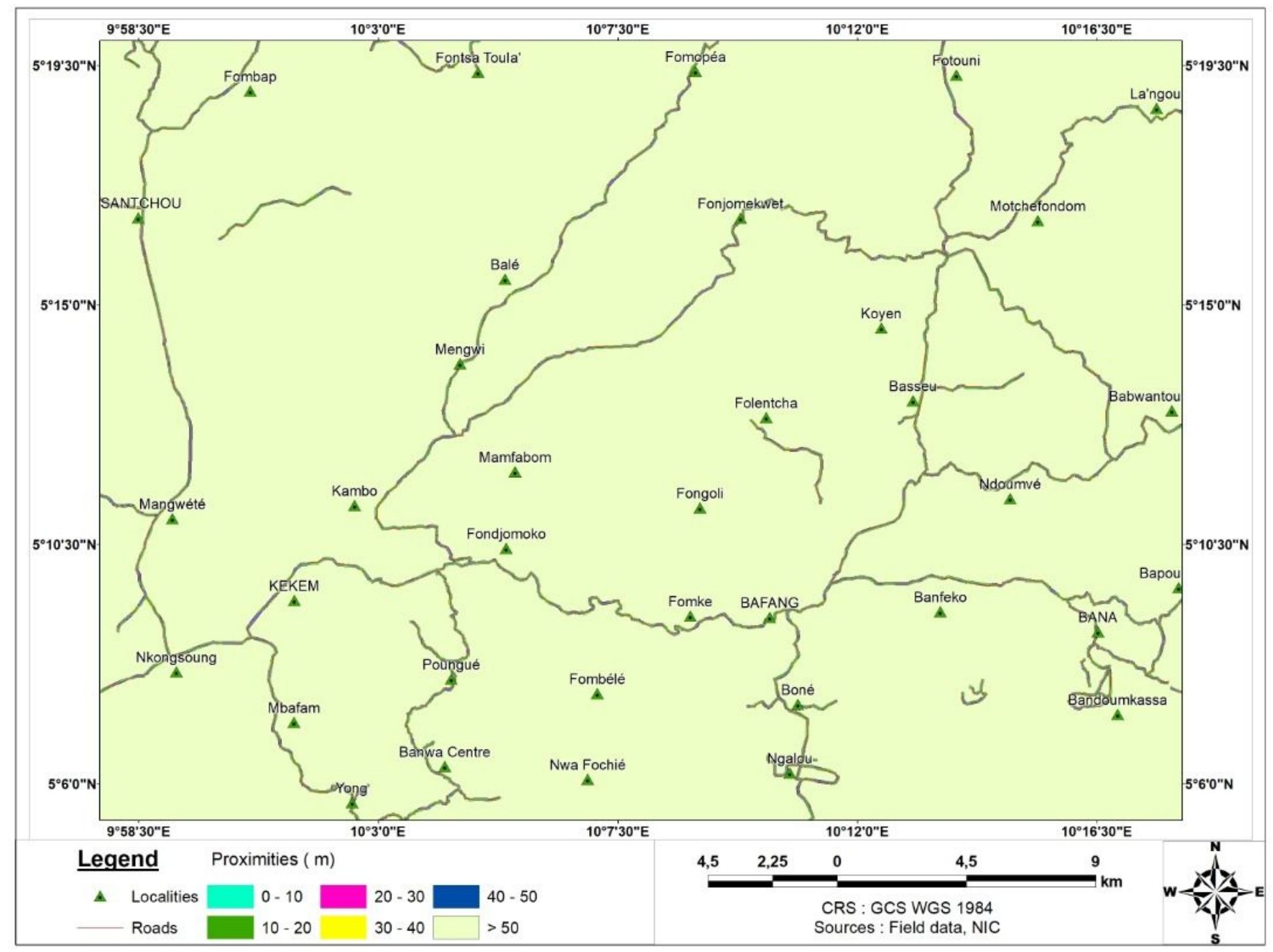

Figure 16

Road proximity map of the SEBP 


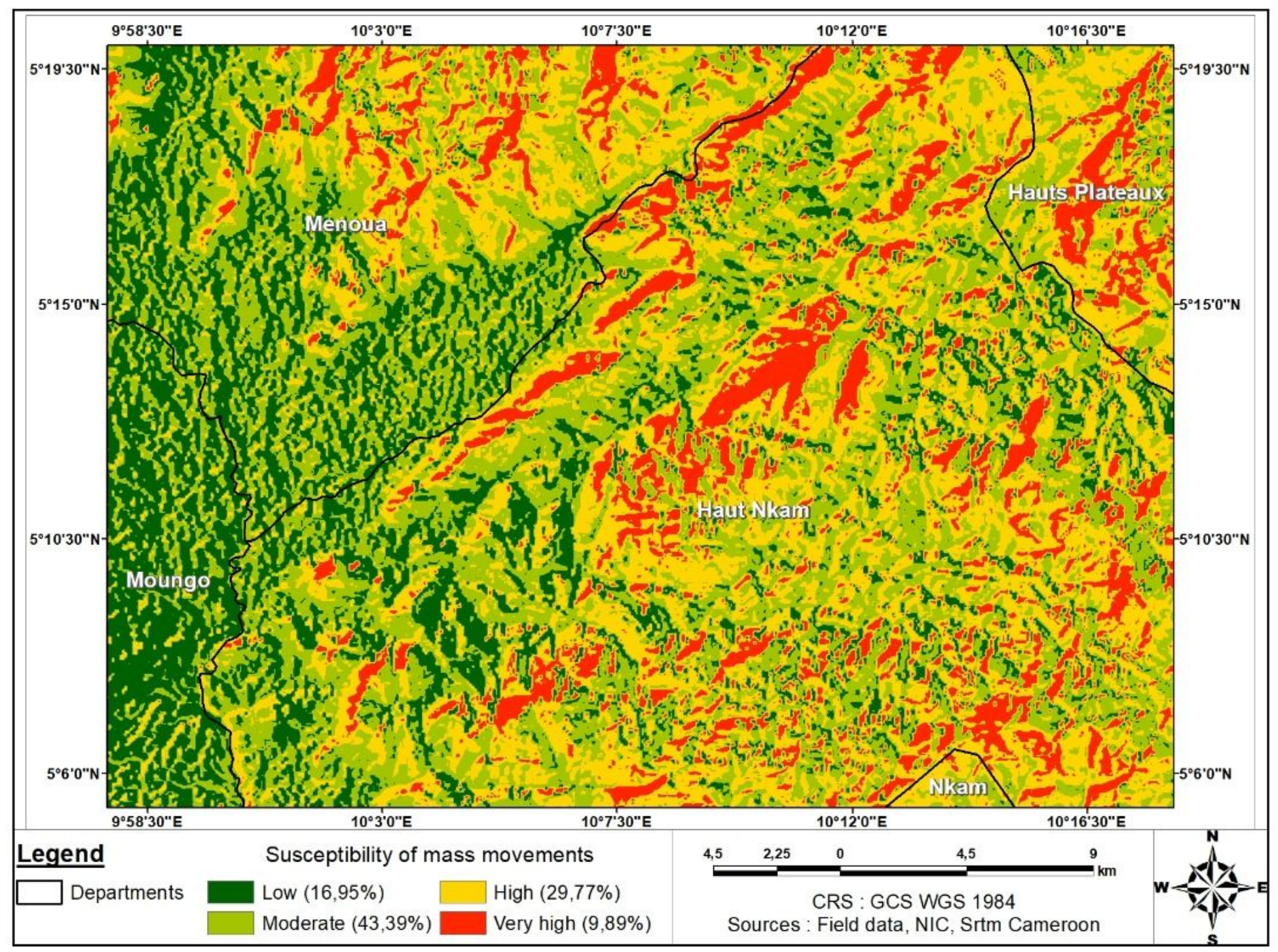

Figure 17

Mass movement susceptibility map of the SEBP 


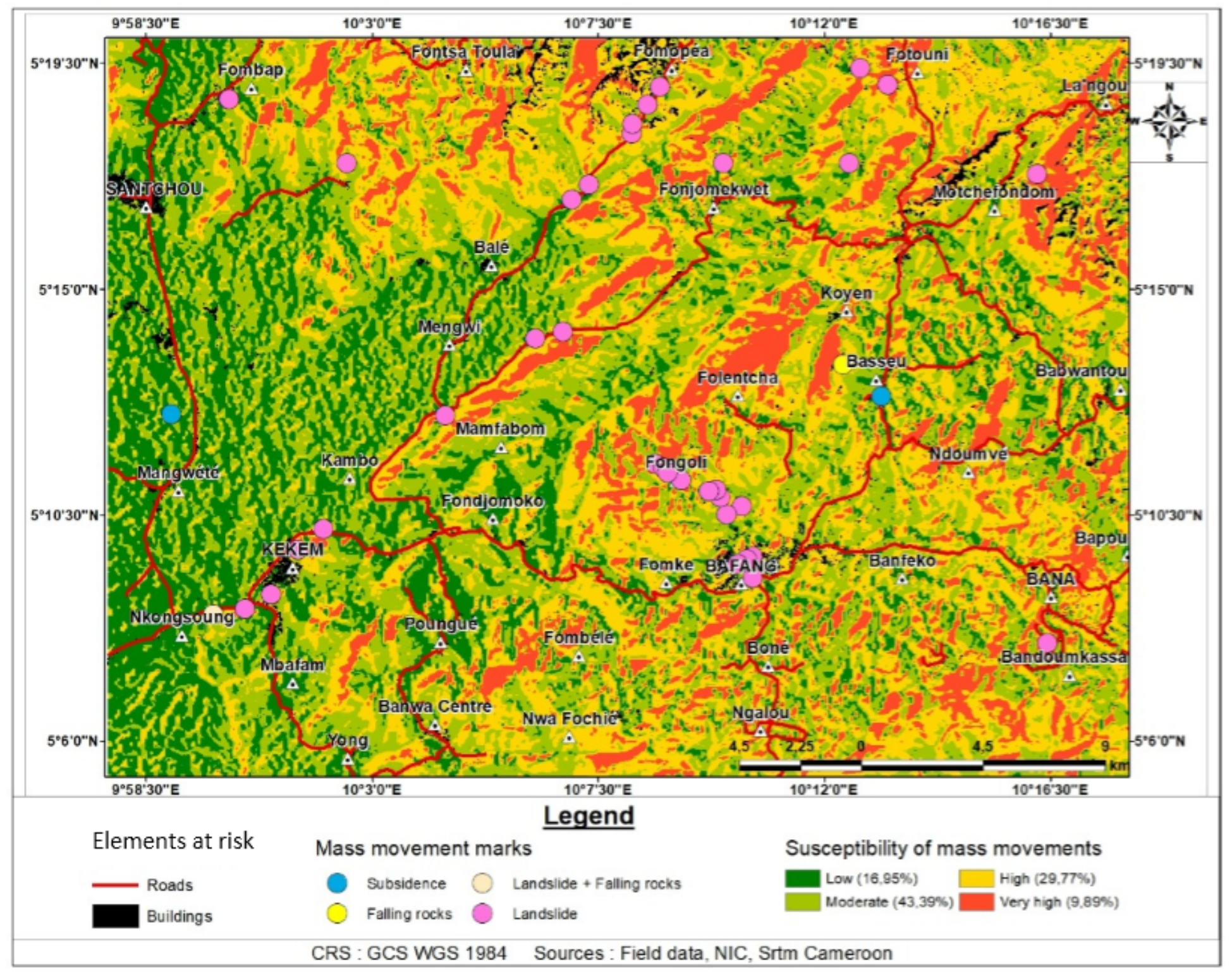

Figure 18

Mass movement susceptibility map with vulnerable sites of the SEBP 